\author{
Magdalena Rekść \\ Katedra Teorii Polityki i Myśli Politycznej \\ Uniwersytet Łódzki \\ magdalena.reksc@uni.lodz.pl
}

\title{
KOMUNIKACJA SYMBOLICZNA W PODAYTOŃSKIEJ BOŚNI I HERCEGOWINIE
}

Podaytońska Bośnia i Hercegowina $(\mathrm{BiH})$ to kraj pełen różnego rodzaju paradoksów: politycznych, społecznych, gospodarczych, kulturowych, a nawet językowych (Katnić-Bakaršić 2013: 113-130). Bałkaniści pozostają zgodni co do tego, że układ pokojowy z 1995 roku stworzył warunki dla etnocentryzmu (Kazaz 2013: 205), a to w realiach bośniackiej wielokulturowości nie może prowadzić do budowy stabilizacji i rozwoju państwa. Mieszkańcy tego kraju stale zmagają się z głębokim chaosem wynikającym z kuriozalnego systemu etnicznych parytetów, podziału na entitety ${ }^{1}$ (Buras-Marciniak 2019: 290-291; Sahadžić 2011: 18-23), stawiania interesów narodowych ponad interes państwa, wszechobecnej korupcji. $\mathrm{W}$ analizach dotyczących $\mathrm{BiH}$ nierzadko pojawia się termin „państwo upadłe”, co - choć jest zdecydowaną przesadą i nadinterpretacją - trafnie oddaje skalę zamętu. Jednym z dowodów słabości i dysfunkcjonalności podaytońskiego tworu jest brak komunikacji symbolicznej pomiędzy trzema narodami konstytutywnymi, współistniejącymi nie razem, ale obok siebie.

Serbowie, Chorwaci i Boszniacy, choć mówią językami bardzo podobnymi i bez problemu się rozumieją (niektórzy twierdzą, iż języki powstałe na gruzach dawnego serbo-chorwackiego to w istocie nadal jeden, policentryczny język), nie komunikują się ze sobą w sferze symbolicznej, przede wszystkim za sprawą braku wspólnego aparatu symbolicznego umożliwiającego jedność rozumienia i interpretowania tych samych symboli. Jeśli przyjąć, że komunikowanie to jeden z kluczowych elementów tożsamości grupowej (Pilarska 2014: 39-40), brak takowego w Bośni na poziomie państwa świadczy o jego słabości i kruchości.

${ }^{1}$ Na mocy układu z Dayton, Bośnia i Hercegowina składa się z dwóch jednostek składowych, tzw. entitetów: Republiki Serbskiej oraz Federacji Bośni i Hercegowiny. 
Rolą niniejszego tekstu jest wyjaśnienie zagadnienia komunikacji symbolicznej jako czynnika niezbędnego dla konsolidacji społeczeństwa oraz wykazanie, że brak takowego w $\mathrm{BiH}$ potwierdza przyjmowaną powszechnie tezę o ogromnych podziałach społecznych i barierach mentalnych, które nie tylko nie słabną, ale nawet narastają, skutkiem czego po upływie ćwierci wieku od zakończenia konfliktu w kraju tym panuje pokój negatywny (Ćurak), a eksperci prognozują nieuchronność destabilizacji politycznej, albo nawet wybuchu kolejnej wojny.

Komunikacja symboliczna, uważana za szczególny typ komunikacji, właściwy jedynie gatunkowi Homo sapiens (Grouchy, D’Euleterio, Christiansen, Lipson 2016), polegający na wymianie informacji na poziomie abstrakcyjnym, za pomocą symboli, stanowi przedmiot zainteresowania nie tylko semiotyków. Wielokulturowość, globalizacja, szybki przepływ danych i postępujące usieciowienie relacji społecznych prowokują pytania o specyfikę komunikowania $\mathrm{w}$ ponowoczesności, skoro - jak zauważają znawcy przedmiotu - znakiem nowych czasów okazuje się wszechobecna dyfuzja ekspresji symboli (Miller, Fox 2007: 55). Jeśli istotą komunikacji symbolicznej jest wymiana symboli między jej uczestnikami, przy założeniu o jedności rozumienia i interpretacji tych symboli, to zauważyć trzeba, że w realiach XXI wieku coraz większe znaczenie uzyskują nietradycyjne formy komunikowania, również między reprezentantami różnych kręgów cywilizacyjnych, zakorzenionych w odmiennych przestrzeniach symbolicznych. To otwiera pytania o szanse porozumienia w sytuacji zakotwiczenia uczestników dyskursu w różnych kontekstach mentalnościowych i sferach aksjonormatywnych.

Niniejszy tekst poświęcony zostanie $\mathrm{BiH}$ - krajowi z jednej strony określanemu często metaforą pogranicza, $\mathrm{z}$ drugiej zaś przesiąkniętego $\mathrm{w}$ ostatnich latach praktykami etnicznej segregacji, budowania narracji tożsamościowych za pomocą podkreślania i przejaskrawiania wszelkich różnic, co w konsekwencji doprowadziło do wykształcenia się trzech odrębnych kulturowo-identyfikacyjnych imaginariów.

Jak zauważono, pomimo iż mieszkańcy $\mathrm{BiH}$ mówią językami bardzo podobnymi do siebie, a - według niektórych - nawet jednym językiem, nie ma pomiędzy nimi porozumienia na poziomie symbolicznym. Wyjaśnienie takiego stanu rzeczy rozpocząć należy od refleksji na temat symboli i ich roli w kreowaniu tożsamości i pamięci zbiorowej, następnie zaś ukazany zostanie brak wspólnych narracji bośniackich, co stanowi jeden z dowodów potwierdzających powszechne tezy na temat niewydolności państwa bośniackiego, co z kolei prowokuje pytania o jego przyszłość.

Symbol to znak posiadający, oprócz dosłownego, również ukryte, głębsze, zmetaforyzowane znaczenie (Durand 1986: 29), tak samo odczytywane przez 
członków zbiorowości. Symbole nie istnieją w oderwaniu od siebie, ale w nieskończenie wielkich zespołach, które nabywane są przez jednostkę w procesie socjalizacji. Przedstawicieli różnych nauk fascynuje przede wszystkim abstrakcyjna wymowa i przesłanie symboli, ich walory artystyczne, a także funkcje społeczne, kulturowe, polityczne. Nie ulega wątpliwości, iż kodowanie i interpretowanie rzeczywistości poprzez zbiory symboli stanowi pewną własność człowieka, co zresztą trafnie oddaje pojęcie Ernsta Cassirera animal symbolicum. Symbole kształtują tożsamość, współtworzą wyobrażenia zbiorowe, kreują społeczno-kulturowy know-know umożliwiający odnalezienie się w rzeczywistości (Hall 1997: 22). Hannah Arendt pisała, że symbole zapewniają jedność ludzkiego doświadczenia (Arendt 1991: 61), czym sugerowała, że harmonizują pola semantyczne członków grupy. Nie podlega bowiem dyskusji, że spajanie zbiorowości na przestrzeni mentalnej poprzez wspólny aparat symboliczny otwiera pole dla sprawnego procesu komunikowania. Bez systemu wspólnych, prostych symboli, o powszechnie wiadomym znaczeniu, nie istniałyby koherentne wizje świata czy kody porozumiewania się, co znajduje swoje odniesienie również do sfery polityki.

Pośród badań dotyczących symboli centralne miejsce zajmują studia nad językiem jako zorganizowanym systemem symbolicznym. Jak twierdził Ferdinand de Saussure, język to zinstytucjonalizowane, wypełnione metaforami narzędzie myślenia i komunikacji (Holdecroft 1991). Tymczasem interesujący mnie w niniejszym tekście casus $\mathrm{BiH}$ pokazuje, że język stanowi tylko jedną $\mathrm{z}$ bardzo wielu składowych systemu symboli zbiorowości, skoro językowa bliskość jego mieszkańców nie idzie w parze z porozumieniem na płaszczyźnie mentalnej.

George Herbert Mead, uznawany za jednego z twórców pragmatyzmu społecznego oraz interakcjonizmu symbolicznego, przekonywat, że jednostki, przynależąc do różnych grup społecznych, podporządkowują się ich systemom aksjonormatywnym, a więc - innymi słowy - internalizują systemy wartości w nich obowiązujące (Kolankiewicz 2005: 15). Przy tym oczywistością jest stwierdzenie mówiące o występującym współcześnie pluralizmie tożsamościowym, identyfikowaniu się z różnymi grupami: etnicznymi, religijnymi, językowymi, zawodowymi itd. Ponadto w realiach XXI wieku i postępującego usieciowienia relacji społecznych pluralizm tożsamości wydaje się jeszcze bardziej wyraźny. Rację ma Mariusz Zemło, kiedy podkreśla, że odgrywanie wielu ról i funkcjonowanie $\mathrm{w}$ różnych kontekstach działań może prowadzić do chaosu i zagubienia się jednostki. W tej sytuacji przyjmuje ona zazwyczaj taką postać wiedzy, która będzie dla niej najbardziej użyteczna i na swój sposób atrakcyjna (Zemło 2013: 24). Odnosząc to spostrzeżenie do BiH jako strefy przejściowej, gdzie nakładają się na siebie różne etnosy, kultury i religie, nietrudno zauważyć, 
że mieszkańcy tego kraju traktują tożsamości etniczne: serbską, chorwacką, boszniacką jako najbardziej naturalne, zaś koncepcja ponad etnicznej wspólnoty bośniackiej dla większości mieszkańców brzmi abstrakcyjnie. Bywa nawet postrzegana jako zagrożenie dla tożsamości etnicznych. Rację ma Krzysztof Krysieniel twierdzący, że wypracowana przez zachodnich ekspertów formuła układu pokojowego z Dayton ustanowiła etniczność fundamentem państwa, a tożsamość etniczna stała się najwyższą wartością prawno-ustrojową (Krysieniel 2012: 251-260).

Justyna Pilarska zauważa, że bośniacka wielokulturowość i usytuowanie kraju na pograniczu wielu kręgów cywilizacyjnych stwarzają dobre warunki dla transferu norm, wartości, obyczajów w ramach międzykulturowego dialogu (Pilarska 2015: 62-65). Niestety, Bośnia nie jest w stanie wykorzystać swojego ogromnego potencjału w postaci unikalnej hybrydy tożsamościowej, co więcej, skomplikowany charakter etniczny bywa często wymieniany jako jedna z przyczyn problemów politycznych. Winą za taki stan rzeczy ponoszą nie tylko zachodni architekci porozumienie z Dayton, ale również lokalne elity polityczne, z których przeważająca większość nie potrafi albo nie chce myśleć i działać na rzecz pojednania w celu budowy dobrobytu państwa. Politycy wolą wykorzystywać władzę dla realizacji prywatnych interesów, a najprostszą strategią wygrania wyborów jest odwoływanie się do retoryki nacjonalistycznej i powielanie negatywnych stereotypów odnośnie sąsiadów, skutkiem czego Serbowie, Chorwaci i Boszniacy mieszkają obok siebie, ale nie współtworzą jednej wspólnoty.

Eksperci często wskazują, że popularne w BiH frazy jak „narodowy interes” czy „prawo do różnorodności” są nadużywane i instrumentalnie wykorzystywane, co pogłębia paraliż państwa i nie sprzyja budowaniu atmosfery pojednania (Hromadžić 2017: 83-84). Jak pisze Mijana Kasapović, założony przez wspólnotę międzynarodową model demokracji konsocjonalnej nie może funkcjonować, skoro nie istnieje - choćby minimalne - pole dla konsensusu pomiędzy trzema narodami konstytutywnymi (Kasapović 2005: 162). Na marginesie warto uściślić, że przyjęta w Dayton wizja polityki etnicznej w Bośni nie tylko nie służy stabilizacji i implementacji trwałego pokoju, ale również dyskryminuje mniejszości etniczne, a więc osoby nie identyfikujące się z żadną z trzech dominujących nacji (Štiks 2016: 280; Krysieniel 2012: 125).

Wszechobecny, ciągle pogłębiający się chaos w państwie uwidacznia się praktycznie w każdej dziedzinie życia, również $\mathrm{w}$ dyskusjach dotyczących języka. Każdy z trzech konstytutywnych narodów traktuje język jako jeden $\mathrm{z}$ fundamentów tożsamości narodowej i obawia się o nasycanie go wplywami sąsiadów (Katnić-Bakaršić 2013: 122, 131). Nietrudno to wyjaśnić specyfiką bośniackich realiów, gdzie można mówić o tożsamościach zagrożonych, 
projektowanych w atmosferze strachu przed „obcymi”. W takiej sytuacji język staje się jednym z najważniejszych i najbardziej oczywistych symboli, wokół których budowana jest tożsamość grupowa (Bugarski 2004: 126). Boszniacy nazywają go bośniackim (bosanski), podczas gdy bośniaccy Chorwaci i Serbowie domagają się określania go językiem boszniackim (bošnjački). O niemożności wypracowania konsensusu świadczy fakt, iż konstytucja $\mathrm{BiH}$ nie porusza tego zagadnienia (Katnić-Bakaršić 2013: 119).

Pomimo wspominanych sporów, języki mieszkańców Bośni są do siebie bardzo podobne, natomiast zasadniczy problem w komunikacji stwarzają stale pogłębiające się bariery mentalnościowe, którym zostanie poświęcona dalsza część tekstu. Pośród powodów takiego stanu rzeczy wymienić warto przede wszystkim: odrębne programy nauczania, różne wersje przeszłości, rozbieżne oczekiwania co do przyszłości państwa, brak wspólnej, bośniackiej tożsamości, nieistnienie wspólnego kapitału symbolicznego.

W BiH istnieją trzy odrębne programy nauczania. W Republice Serbskiej obowiązują nie tylko serbskie programy nauczania, ale młodzi ludzie korzystają z serbskich podręczników i pomocy naukowych, przez co zapoznają się z serbską, a nie bośniacką historią, geografią i literaturą (Bartulović 2006: 53-54; Bose 2002: 134-135). W Federacji $\mathrm{BiH}$ w kantonach zdominowanych przez Chorwatów ${ }^{2}$ sytuacja wygląda podobnie, tyle tylko że materiały przywożone są z Chorwacji. Na obszarach etnicznie mieszanych Federacji BiH istnieje zjawisko tzw. dwóch szkół pod jednym dachem, bardzo często określane jako przejaw dyskryminacji (Raport OSCE), odnoszące się do sytuacji, gdy boszniackie i chorwackie dzieci uczą się w jednym budynku, ale w oparciu o różne programy nauczania, a te wyprofilowane są $\mathrm{w}$ sposób nie koncyliacyjny, ale konfrontacyjny (Palmberger 2016: 94-97). Aza Hromađić w książce będącej rezultatem badań terenowych $\mathrm{w}$ jednej z takich szkół w Mostarze opisuje etniczne rozgraniczenie budynku na to co chorwackie i to co boszniackie oraz paradoksy z tego wynikające. Wykazuje przy tym, iż w podzielonym budynku znalazło się jednak miejsce dla wspólnej integracji, którym była toaleta, przy czym służyła ona młodzieży przede wszystkim do nielegalnego palenia papierosów. Palenie w ukryciu okazało się jedyną szansą dla międzyetnicznego dialogu, który zazwyczaj traktowany był jako coś nietypowego - ekstremalna przygoda, robienie rzeczy niedozwolonych, niezgodnych z ogólnie przyjętymi schematami postępowania (Hromadžić 2017: 138-142).

Etniczna segregacja występuje również na poziomie szkolnictwa wyższego, przede wszystkim na uczelniach finansowanych przez Republikę

${ }^{2}$ Federacja BiH składa się z dziesięciu kantonów, z których trzy są zdominowane przez Chorwatów, pięć przez Boszniaków, a dwa mają charakter mieszany. 
Serbską lub zdominowane przez Chorwatów kantony. O ile na przykład na uniwersytecie w Sarajewie studenci mogą zdawać egzaminy w wybranym wariancie języka, co ma być wyrazem otwartości i tolerancji na różnorodność (Katnić-Bakaršić 2013: 125), to kształcenie na „etnicznych” uczelniach w oparciu o serbską lub chorwacką wizję rzeczywistości stwarza realne problemy dla funkcjonowania bośniackiego państwa. Nie chodzi tutaj tylko o subtelności językowe, ale umacnianie podziałów wewnętrznych poprzez edukację w oparciu o różne porządki symboliczne, zwłaszcza na gruncie nauk humanistycznych i społecznych. Warto dodać, że wspomniana tolerancja językowa stołecznej uczelni może z jednej strony wynikać ze specyfiki tegoż miasta - które choć w powojennej Bośni z ośrodka wielokulturowego przekształciło się w centrum dominacji boszniackiej, wciąż pielęgnuje atmosferę wielokulturowości (Rathfelder 2007: 27; Šavija-Valha 2013: 116-122) - z drugiej zaś Boszniacy, stanowiący według oficjalnego spisu z 2013 roku niewiele ponad połowę (50,11\%) ludności (Popis stanovništva ... : 56) i niemający innych państw, z którymi (w odróżnieniu od sąsiadów) mogliby się identyfikować, jako jedyna z nacji współtworzących Bośnię opowiadają się za umacnianiem jej integralności terytorialnej.

Bariery mentalne, wyznaczające niewidzialne granice pomiędzy narodami konstytutywnymi $\mathrm{BiH}$ wynikają również z odrębnych wizji historii, tymczasem nie podlega dyskusji pogląd, zgodnie z którym wspólna przeszłość stanowi jeden $\mathrm{z}$ najważniejszych elementów konsolidacji zbiorowości. Tymczasem każdy z narodów konstytutywnych posiada i kultywuje własną wizję dziejów, które mają ze sobą mało punktów wspólnych, obfitują za to w przeciwstawnie postrzegane i interpretowane wydarzenia. Nie mając miejsca na bardziej szczególowe przeanalizowanie tego zagadnienia (zob. Rekść 2011: 381-409), ograniczę się do jednego przykładu, który dowodzi braku porozumienia mieszkańców BiH na płaszczyźnie symbolicznej. Masakra w Srebrenicy stanowi mit założycielski tożsamości boszniackiej i uznawana jest w Federacji BiH za ludobójstwo, za którego negowanie można zostać pociągniętym do odpowiedzialności karnej. Natomiast Republika Serbska (w odróżnieniu od linii politycznej Belgradu) zupełnie inaczej patrzy na tamte wydarzenia - interpretuje je jako jedną z bardzo wielu zbrodni, będących odpowiedzią na wcześniejsze okrucieństwa popełnione przez Boszniaków na Serbach (Korczyński 2011: 449-457). Na poziomie państwowym nie obowiązuje żadna ustawa o odpowiedzialności karnej za negowanie zbrodni wojennych (Huseinović), bowiem bośniaccy politycy nie potrafią uzgodnić jej formuły właśnie za sprawą odmiennych interpretacji przeszłości. Przykład ten wyraźnie pokazuje skalę różnic na poziomie mentalności w bośniackim społeczeństwie, a w takiej sytuacji trudno mówić o wspólnych kanałach komunikacyjnych. 
Różne wizje przeszłości nakładają się na przeciwstawne spojrzenia na teraźniejszość i przyszłość państwa. Serbowie definiują swoją tożsamość zbiorową, spoglądając na Belgrad i Moskwę, Chorwaci na Zagrzeb, co dodatkowo wzmogła akcesja Chorwacji do Unii Europejskiej w 2013 roku (Sarajlić 2012: 156-157), zaś autoidentyfikacja Boszniaków fundowana na pierwiastku orientalnym (Jawoszek 2014: 50-51), idzie w parze z umacnianiem sojuszy ze Stambułem i państwami Bliskiego Wschodu. Różne warianty tożsamości, pozostające w ścisłym związku z trzeba odrębnymi wektorami cywilizacyjno-kulturowymi, rzutują na brak spójnej wizji polityki zagranicznej państwa. I tak chociażby Chorwaci i Boszniacy opowiadają się za integracją z NATO, Serbowie zaś się temu stanowczo sprzeciwiają. Przepaść mentalna dzieląca mieszkańców BiH uwidacznia się również przy okazji kontrowersyjnych wydarzeń międzynarodowych, jak np. konflikt na Ukrainie. W takich sytuacjach rozbieżność w interpretowaniu rzeczywistości umacnia istniejące podziały, tworząc nowe zasoby negatywnych emocji. Pomimo względnej zgody elit politycznych co do chęci akcesji do UE, różnice zdań i trudności z wypracowaniem konsensusu znacznie utrudniały przygotowanie formalnego wniosku o członkostwo, który złożono dopiero w roku 2016.

Brak jednolitej wizji geopolitycznej uniemożliwia prowadzenie spójnej polityki zagranicznej, również na poziomie placówek dyplomatycznych. Według konstytucji $\mathrm{BiH}$ prezydium (kolegialna głowa państwa) mianuje ambasadorów, przy czym maksymalnie $2 / 3$ z nich może zostać wyłonionych z terenów Federacji (Ustav Bosne i Hercegovine), co w praktyce oznacza, iż około 1/3 ambasadorów wyznaczana jest przez Republikę Serbską. Tak więc bośniaccy ambasadorowie realizują trzy różne wizje polityki zagranicznej, w inny sposób budują i promują wizerunek kraju na arenie międzynarodowej.

$\mathrm{W}$ podzielonej na poziomie mentalności $\mathrm{BiH}$ brakuje wspólnego kapitału symbolicznego, a więc symboli akceptowanych przez wszystkie narody konstytutywne. Każdy z entitetów wypuszcza własne wersje banknotów, przedstawiające odmienne postacie. Wspólny dla obu entitetów jest jedynie banknot o nominale $200 \mathrm{KM} \mathrm{z}$ wizerunkiem Ivo Andricia oraz mostu w Višegradzie. Banknoty o nominałach 10, 20, 50 oraz $100 \mathrm{KM}$ wydawane są w dwóch wersjach. Narody konstytutywne $\mathrm{BiH}$ nie potrafią również wypracować konsensusu odnośnie do słów hymnu narodowego, a zatem ich kraj musi zadowolić się samą melodią.

$\mathrm{Na}$ obszarach etnicznie mieszanych dużym wyzwaniem pozostaje znalezienie wspólnego bohatera, którego imieniem można byłoby nazwać ulice, szkoły, instytucje, i którego warto byłoby czcić. $\mathrm{W}$ podzielonej etnicznie, religijnie i mentalnie stolicy Hercegowiny, wobec braku wspólnych bohaterów godzących Chorwatów i Boszniaków - po serii ankiet po obu stronach odnośnie 
postaci utożsamianych z solidarnością, sprawiedliwością i tolerancją - wzniesiono pomnik Bruce'a Lee (Polly 2018: 493).

Brak porozumienia pomiędzy narodami wspóltworzącymi BiH widoczny jest również w projekcjach dotyczących przyszłości. Serbowie traktują $\mathrm{BiH}$ jako państwo tymczasowe, powielają narracje o nieuchronności jego rozpadu, co idzie w parze z zapowiedziami proklamacji niezależności przez RS i przyłączeniu jej do Serbii. Tyle tylko, że takie rozwiązanie nie jest ani na rękę aspirującemu do UE Belgradowi, ani przywództwu bośniackich Serbów, są to raczej jedynie puste slogany obliczone na zapewnienie doraźnych celów politycznych. Tak czy inaczej retoryka tego rodzaju nie sprzyja umacnianiu integralności terytorialnej BiH. Również bośniaccy Chorwaci postrzegają Bośnię jako twór sztuczny i przejściowy, tyle tylko że będąc najmniejszym z trzech konstytutywnych narodów, nieposiadającym tak znaczących sojuszników, jak sąsiedzi (Moskwa, Stambul), koncentrują się przede wszystkim na utworzeniu swojego własnego entitetu. Boszniacy jako jedyni uważają Bośnię za własne państwo oraz pragną jego rozwoju i wzmocnienia, co wydaje się w pełni zrozumiałe, skoro nie posiadają oni drugiej, „zapasowej” ojczyzny. Rację ma Mirjana Kasapović, która twierdzi, że niemożliwa jest trwała budowa stabilizacji w Bośni, gdyż bośniaccy Serbowie oraz Chorwaci pierwszoplanowo traktują lojalność wobec Serbii czy Chorwacji (Kasapović 2005: 15-17). Emin Eminagić dodaje, że w tym bałkańskim kraju nakładają się na siebie trzy nacjonalistyczne imaginaria, z których każde oparte jest na maksymie dziel i rządź (Eminagić 2017: 30).

Trzeba przyznać, że pomimo naszkicowanych trudności w budowaniu wspólnego państwa, istnieją w Bośni osoby wskazujące na konieczność budowy wspólnej, ponadetnicznej tożsamości zbiorowej. Ich inicjatywy nie mają jednak szansy przebicia się w społeczeństwie, w którym dominuje nacjonalistyczna wizja rzeczywistości, a każdy z narodów nieprzerwanie walczy o umacnianie swojej tożsamości. Nieliczne grono entuzjastów, do którego zaliczają się przede wszystkim elity intelektualne, ludzie kultury, organizacje pozarządowe, a także niektórzy duchowni próbuje promować ideę bośniackiej autoidentyfikacji. Wobec braku porozumienia w procesie komunikacji symbolicznej i niedostatku wspólnego kapitału symbolicznego pojawiają się próby jego stworzenia, bowiem jak słusznie zauważa Vjekoslav Perica, tylko w ten sposób można zbudować trwałą wspólnotę wyobrażoną (Perica 2012: 181-183).

Spośród kilku postaci, które próbuje się uczynić ikonami bośniackiej tożsamości centralne miejsce zajmuje Srđan Aleksić (bośniacki Serb z Trebinja, który zginął z 1993 roku, występując w obronie swojego boszniackiego sąsiada), służący zresztą za bohatera kręgom antynacjonalistycznym na obszarze całej byłej Jugosławii. W roku 2008 ponad 100 organizacji pozarządowych, przede wszystkim z Serbii oraz $\mathrm{BiH}$ wystosowało apel do całego regionu o nazywanie 
ulic mianem bohatera z Trebinja (Moll 2016: 5), który ochoczo podjęły niektóre miasta, w tym. np. Sarajewo. Jedna z bośniackich organizacji trzeciego sektora (Post-Conflict Research Center) ustanowiła konkurs Srđan Aleksić Youth Competition skierowany do młodych ludzi w Bośni, którzy na co dzień przekraczają etniczne bariery w celu zmiany świata na lepsze. Podobnych inicjatyw pojawia się corocznie bardzo wiele, nie tylko w $\mathrm{BiH}$. Tzw. Srđo stał się również ikoną kultury popularnej, a jego ojciec (z zawodu trener koszykówki) udziela wielu wywiadów dotyczących bohaterstwa syna, stając się niemalże lokalnym celebrytą.

Kult Aleksicia nie jest szczególnym wyjątkiem, ponieważ już od zakończenia wojny w Bośni zaczęto zbierać historie o „dobrych ludziach w czasach zła”, by użyć tytułu wydanej również w Polsce książki autorstwa Svetlany Broz, wnuczki Josipa Broza Tity. Podobnych inicjatyw było znacznie więcej, tyle tylko, iż nie dostały nigdy szansy przebicia się do oficjalnego dyskursu (Moll 2019: 430-453). Tymczasem postać Aleksicia zjednuje sobie sojuszników z różnych nacji i opcji politycznych (Moll 2016: 6-7) najprawdopodobniej dzięki uniwersalnemu przekazowi narracji o młodym człowieku, artystycznej duszy, od początku niechętnemu walczyć przeciwko sąsiadom i przyjaciołom. Dodatkowo Serbowie, którym ciągle przypisuje się zasadniczą odpowiedzialność za krwawe konsekwencje rozpadu Jugosławii, dostrzegają w nowym bohaterze szansę na zmianę ich postrzegania na zewnątrz, nic więc dziwnego, iż próby jego heroizacji występują również w Serbii.

Vjekoslav Perica proponuje, aby w procesie poszukiwania postaci herosów, akceptowalnych pośród skonfliktowanych nacji, sięgnąć po gwiazdy sportu, jak np. słynny koszykarz Mirza Delibašic - gwiazda Bośni Sarajewo i Realu Madryt oraz pierwszy selekcjoner reprezentacji niepodległej BiH (Perica 2012: 196-198). Chorwacki historyk miał słuszność, sugerując, że bohaterom sportowym łatwiej pokonać etniczne podziały, tyle tylko, że Delibašić nie był do końca „narodowo neutralny”, a sam Perica przyznaje, że w burzliwych latach dziewięćdziesiątych XX wieku reżim Slobodana Miloševicia negatywnie go etykietowal, oskarżając nawet o zbrodnie wojenne (Perica 2012: 198-199). Łatwo zauważyć, iż taka odmiennie interpretowana postać nie może urosnąć do rangi wspólnego, ponad etnicznego symbolu łączącego zwaśnione nacje.

Z tego też powodu łatwiej szukać nowych herosów wśród postaci niekontrowersyjnych, a przez to łatwiej akceptowalnych przez wszystkie strony. W Mostarze, obok wspomnianego popiersia Bruce’a Lee, pojawił się pomysł wzniesienia pomnika lokalnemu bohaterowi, uważanemu za „legendę miasta” - „Acy rowerzyście”, jak miejscowi nazywali Aleksandra Džakulę. Pochodzący z Serbii Džakula, prosty, biedny człowiek, codziennie przemierzający miasto rowerem i żartujący, że doskonali formę przed startem w Tour de France, zyskał ogromną 
sympatię zarówno Chorwatów, jak i Boszniaków - jedni i drudzy pomagali mu w ostatnich latach życia („Zaslužuje li Aco spomenik u Mostaru?”).

Oddolna inicjatywa mieszkańców stolicy Hercegowiny jak dotąd nie doczekała się realizacji, warto jednak zwrócić uwagę na jej apolityczny charakter. Bardzo możliwe, że podzielony naród nie jest gotowy na bohaterów o wyraźnych poglądach, którzy w trudnych momentach dziejów opowiadali się po określonych stronach konfliktu. Niewykluczone, że w początkowej fazie konstruowania bośniackiej tożsamości należy zacząć od poszukiwań bohaterów-symboli mniej znanych, ale za to niebudzących sporów. Można jednak stwierdzić, że obranie takiej strategii dodatkowo unaocznia słabość Bośni jako państwa, bowiem Srđan Aleksić czy tym bardziej Aca rowerzysta to postacie z nurtu mikrohistorii, ciągle traktowanej jako awangarda, ciekawa alternatywa, ale nie substytucja metanarracji. Jeśli przyjąć, że historia rozumiana jako wielka opowieść o przeszłości stanowi nieodzowny instrument budowania przynależności grupowej, refleksja ta jest potwierdzeniem pesymistycznych, ale niestety dominujących prognoz dotyczących przyszłości bośniackiego państwa.

Reasumując, rozwiązania przewidziane w układzie pokojowym z Dayton - choć spełniły swój zasadniczy cel, jakim było zakończenie najkrwawszego konfliktu w Europie po II wojnie światowej - stworzyły w BiH jeden z najbardziej kuriozalnych systemów politycznych, którego ćwierć wieku funkcjonowania można określić jako postępującą destabilizację państwa. Jednym z istotnych przejawów dysfunkcjonalności podaytonowskiej $\mathrm{BiH}$ jest komunikacja symboliczna, a właściwie jej brak pomiędzy Serbami, Chorwatami i Boszniakami. Pomimo mentalnej gettoizacji, istnieją w Bośni środowiska próbujące tworzyć i upowszechniać jednoczące kody symboliczne - tak potrzebne w procesie budowania wspólnej tożsamości jako szansy umocnienia, a może nawet i przetrwania państwa. Niestety, jak dotąd, ich siła przebicia jest zbyt słaba, a entuzjastyczne działania nie są w stanie konkurować z dominującymi narracjami.

\section{Bibliografia}

Arendt H. (1991), Myślenie, Warszawa.

Bartulović A. (2006), Nationalism in the classroom: narratives of the war in Bosnia-Herzegovina (1992-1995) in the history textbooks of the Republic of Srpska, „Studies in Ethnicity and Nationalism”, t. 6(3), s. 51-72.

Bose S. (2002), Bosnia after Dayton: Nationalist Partition and International Intervention, London.

Bugarski R. (2004), Jezik u društvu, Beograd. 
Buras-Marciniak A. (2019), Bośnia i Hercegowina. Sytuacja spoteczno-gospodarcza, [w: ] A. Buras-Marciniak (red.), Bośnia i Hercegowina. Kultura, literatura, język, polityka, Łódź, s. 289-303.

Ćurak N., Kako smo postali sekundanti političke desnice?, https://hamdocamo. wordpress.com/2013/10/13/nerzuk-curak-kako-smo-postali-sekundantipoliticke-desnice/ (dostęp: 17.01.2019).

Durand G. (1986), Wyobraźnia symboliczna, Warszawa.

Eminagić E. (2017), Towards a de-ethnicized politics: protests and plenums in Bosnia and Herzegovina, [w:] J. Mujanović (red.), The Democratic Potential of Emerging Social Movements in Southeastern Europe, Sarajevo.

Grouchy P., D’Euleterio G.M.T., Christiansen M.H., Lipson H. (2016), On the evolutionary origin of symbolic communication, "Scientific Reports”, $\mathrm{nr} 6$, https://www.nature.com/articles/srep34615 (dostęp: 25.02.2020).

Hall S. (1997), The work of representation, [w:] S. Hall (red.), Representation: Cultural Representations and Signifying Practices, London-Thousand OaksNew Delhi.

Holdecroft D. (1991), Saussure, Signs, System and Arbitrariness, Cambridge.

Hromadžić A. (2017), Samo Bosne nema. Mladi i stvaranje države u posleratnoj Bosni j Hercegovini, Beograd.

Huseinović S., Negiranje genocida i veličanje ratnih zločinaca, 9.07.2019, https://www.dw.com/bs/negiranje-genocida-i-veli\%C4\%8Danje-ratnihzlo\%C4\%8Dinaca/a-49513369 (dostęp: 12.03.2020).

Jawoszek A. (2014), Boszniacy. Literackie narracje tożsamościowe po 1992 roku, Poznań.

Kasapović M. (2005), Bosna i Hercegovina: podijeljeno društvo i nestabilna država, Zagreb.

Katnić-Bakaršić M. (2013), Bosanskohercegovačka sociolingvistička previranja, [w:] V.V. Požgaj Hadži (red.), Jezik među lingvistike i politike, Beograd.

Kazaz E. (2013), Dejton - Medunarodna legitimizacija ratnih osvajanja, [w:] M. Džolan (red.), Bosna i Hercegovina - Europska zemlja bez ustava, Zagreb-Sarajevo.

Kolankiewicz L. (2005), Wstęp: ku antropologii widowisk, [w:]. L. Kolankiewicz (red.), Antropologia widowisk. Zagadnienia i wybór tekstów, Warszawa, s. $10-32$.

Korczyński W. (2011), Muzutmańska i serbska pamięćo Srebrenicy, [w:] P. Chmielewski, S. L. Szczesio (red.), Bośnia i Hercegowina 15 lat po Dayton. Przeszłość - teraźniejszość - przyszłość, Łódź.

Krysieniel K. (2012), W cieniu Dayton. Bośnia i Hercegowina między etnokracja i demokracja konsocjonalna, Warszawa. 
Miller H.T., Fox C.J. (2007), Postmodern Public Administration, New YorkLondon.

Moll N. (2016), A positive hero for everyone? The memorialization of Srdan Aleksić in post-Yugoslav countries, „Contemporary Southeastern Europe”, no. 3.

Moll N. (2019), Promoting "positive stories” of help and rescue from the 19921995 war in Bosnia and Herzegovina. An alternative to the dichotomy of guilt and victimhood?, „Südosteuroa”, $\mathrm{nr} 4$.

Palmberger M. (2016), How Generations Remember: Conflicting Histories and Shared Memories in Post-War Bosnia and Herzegovina, Basingstoke.

Perica V. (2012), Generacije protiv nacija. Postjugoslavenski diskursi heroizma, [w:] V. Perica, M. Velikonja (red.), Nebeska Jugoslavija. Interakcije političkih mitologia i pop-kulture, Beograd.

Pilarska J. (2014), Wielowymiarowa tożsamość wspótczesnych Bośniaków, Wrocław. Pilarska J. (2015), Researching cultural borderlands. Towards a phenomenological and interpersonal methodology, "Journal of Contemporary Educational Studies", nr 3, s. 60-76.

Polly M. (2018), Bruce Lee: A Life, New York-London-Toronto-Sydney-New Delhi.

Popis stanovništva, domaćinstava i stanova u Bosni i Hercegovini, 2013. Rezultati popisa, http://www.popis2013.ba/popis2013/doc/Popis2013prvoIzdanje. pdfm (dostęp: 1.03.2020).

Raport OSCE (2018), „Two Schools Under One Roof”. The Most Visible Example of Discrimination in Education in Bosnia and Herzegovina, https://www. osce.org/mission-to-bosnia-and-herzegovina $/ 404990$ ?download=true (dostęp: 4.03.2020).

Rathfelder E. (2007), Raskrsnica Sarajevo. Bosna i Hercegovina deset godina poslije Daytona: muslimani, pravoslavci, katolici i jevreji grade zajedničku državu, Tuzla.

Rekść M. (2011), Jeden kraj, trzy historie. Interpretacje przeszłości w podaytonowskiej Bośni i Hercegowinie, [w:] P. Chmielewski, S.L. Szczesio (red.), Bośnia i Hercegowina 15 lat po Dayton. Przeszłość - teraźniejszość - przyszłość, Łódź.

Sahadžić M. (2011), Priroda političkog sistema u Bosni i Hercegovini, [w: ] D. Banović, S. Gavrić (red.), Država, politika i društvo u Bosni i Hercegovini. Analiza postdejtonskog političkog sistema, Sarajevo.

Sarajlić E. (2012), Razmatranje režima državljanstva u postdejtonskoj Bosni i Hercegovini, [w:] Dž. Šo, I. Štiks (red.), Državljani i državljanstvo posle Jugoslavije, Beograd.

Šavija-Valha N. (2013), Raja. Ironijski subiekt svakodnevne komunikacije u Bosni i Hercegovini i raja kao strategija življenja, Zagreb. 
Štiks I. (2016), Državljanin, građanin, stranac, neprijatelj. Jedna povijest Jugoslavije i postjugoslavenskih država, Zaprešić.

Ustav Bosne $i$ Hercegovine, http://www.ccbh.ba/public/down/USTAV_ BOSNE_I_HERCEGOVINE_bos.pdf (dostęp: 13.03.2020).

Zaslužuje li Aco spomenik u Mostaru?, 7.12.2015, https://www.bljesak.info/ lifestyle/flash/zasluzuje-li-aco-spomenik-u-mostaru/141097 (dostęp: 13.03.2020).

Zemło M. (2013), Świadomość potoczna, [w:] K. Sztalt, M. Zemło (red.), Formy świadomości społecznej, Lublin.

\section{Magdalena Rekść \\ SYMBOLIC COMMUNICATION IN POST-DAYTON BOSNIA AND HERZEGOVINA}

(Summary)

Bosnia and Herzegovina is widely considered a dysfunctional state where political institutions do not work. The Dayton agreement has shaped a bizarre system of government in which ethnicity remains the most important value. Such a situation is very dangerous in a multi-ethnic country, considering difficult historical past and the lack of implementation of transitional justice. The three constituent nations of Bosnia and Herzegovina do not live together, but side by side, many speak about ghettoization of the country. This text focuses on the symbolic communication in Bosnia or more precisely, its lack. Although Serbs, Croats and Bosniaks speak very similar languages, they do not understand each other on a symbolic level. Each of them has a different vision of the past, present and future and the heroes become enemies in the discourses of neighbours. It should not come as a surprise that that there is no shared symbolic capital in Bosnia and Herzegovina, but without it a collective identity cannot be created and implemented. There are individuals and circles that try to create common Bosnian identity, but their range and capability are very limited, since the principle of ethnicity and ethnic nationalism plays the most important role. Unfortunately, such a situation confirms the pessimistic forecasts regarding the future of the country.

Key words: Bosnia and Herzegovina, Dayton, symbolic communication, identity, identity politics 